\title{
Influence of acepromazine on the cardiovascular actions of dobutamine in isoflurane-anesthetized horses
}

\author{
Influência da acepromazina sobre os efeitos cardiovasculares da dobutamina \\ em cavalos anestesiados com isofluorano
}

\section{Eduardo Raposo Monteiro ${ }^{\mathrm{II} \mathrm{I}^{*}}$ Juliano Ferreira Fernandes de Souza $^{\mathrm{I}}$ Gustavo Cancian Baiotto $^{\mathrm{II}}$ Giuliano Moraes Figueirón ${ }^{I I}$ Julia da Penha Piccoli Rangel ${ }^{\mathrm{II}}$ Clarisse Simões Coelho $^{\mathrm{I}, \mathrm{II}}$}

\begin{abstract}
The influence of acepromazine (ACP) on the effectiveness of dobutamine (DBT) in increasing blood pressure during isoflurane (ISO) anesthesia was evaluated in six horses. On separate occasions, the horses were randomly assigned to receive $\mathrm{NaCl} 0.9 \%$ (Control), ACP $0.025 \mathrm{mg} \mathrm{kg}^{-1}$ and $\mathrm{ACP}$ $0.05 \mathrm{mg} \mathrm{kg}^{-1}$. The experimental treatment was administered prior to induction of anesthesia. Maintenance of anesthesia was performed under conditions of normocapnia with ISO in oxygen. Dobutamine was administered at progressively increasing infusion rates until mean arterial pressure (MAP) reached $70 \mathrm{mmHg}$ or until a maximum infusion rate of $5.0 \mu \mathrm{g}$ $\mathrm{kg}^{-1} \mathrm{~min}^{-1}$. Compared with baseline, DBT increased heart rate, systolic, diastolic and mean blood pressures in all treatments. However, these variables did not differ among treatments. The target MAP $(70 \mathrm{mmHg})$ was not reached in 2/6, 2/5 and 0/6 horses in the Control, $A C P 0.025$ and $A C P 0.05$ treatments, respectively. The mean dose of DBT to achieve target MAP was $3.5 \pm 1.8,3.7 \pm 1.6$ and $2.7 \pm 1.4 \mu \mathrm{g} \mathrm{kg}^{-1} \mathrm{~min}^{-1}$ in the Control, $A C P_{0.025}$ and $A C P_{0.05}$ treatments, respectively $(P>0.05)$. Under the conditions of this study, premedication with ACP does not interfere with the effectiveness of DBT in increasing blood pressure in horses anesthetized with ISO.
\end{abstract}

Key words: phenothiazines, catecholamines, equine, inhalational anesthesia.

\section{RESUMO}

A influência da acepromazina (ACP) sobre a capacidade da dobutamina (DBT) em elevar a pressão arterial durante a anestesia com isofluorano (ISO) foi avaliada em seis equinos. Em ocasiões diferentes, os animais receberam aleatoriamente $\mathrm{NaCl} 0,9 \%$ (Controle), ACP $0,025 \mathrm{mg} \mathrm{kg}^{-1} e$
ACP $0,05 \mathrm{mg} \mathrm{kg}^{-1}$. O tratamento experimental foi administrado previamente à indução da anestesia. A manutenção da anestesia foi realizada em condições de normocapnia com $I S O \mathrm{em}$ oxigênio. A administração de DBT foi iniciada em doses progressivamente crescentes até que o valor de pressão arterial média (PAM) atingisse $70 \mathrm{mmHg}$ ou até a dose máxima de $5,0 \mu \mathrm{g} \mathrm{kg}^{-1} \mathrm{~min}^{-1}$ Comparado ao basal, a administração da DBT resultou em elevação na frequência cardíaca e pressões arteriais sistólica, diastólica e média em todos os tratamentos. Porém, não houve diferença entre os tratamentos nessas variáveis. A PAM alvo (70mmHg) não foi atingida em 2/6, 2/ 5 e 0/6 animais dos tratamentos Controle, ACP0.025 e ACP0.05, respectivamente. A dose média de DBT para a PAM alvo foi

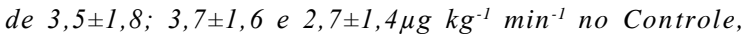
$A C P_{0.025}$ e $A C P_{0.05}$ respectivamente $(P>0,05)$. Nas condições deste estudo, o pré-tratamento com ACP não interfere na eficácia da DBT em elevar a pressão arterial de cavalos anestesiados com ISO.

Palavras-chave: fenotiazinas, catecolaminas, eqüinos, anestesia inalatória.

\section{INTRODUCTION}

Anesthesia of horses remains a major challenge to the veterinary anesthesiologist and is accompanied by a high mortality rate compared with small animals. Intraoperative hypotension and myositis are among the complications responsible for this high mortality rate in horses (JOHNSTON et al., 2002). Intraoperative hypotension results from the effects of

'Programa de Pós-graduação em Ciência Animal, Centro Universitário Vila Velha (UVV). Coordenação do Mestrado em Ciência Animal, UVV, Rua Comissário José Dantas de Melo, 21, Boa Vista, 29102-770, Vila Velha, ES, Brasil. E-mail: eduardo.raposo@uvv.br.

*Autor para correspondência.

"Curso de Medicina Veterinária, UVV, Vila Velha, ES, Brasil. 
anesthetics and anesthetic adjuncts on the cardiovascular system. In horses, tissue perfusion is dependent on adequate cardiac output and blood pressure (LEE et al., 1998). Therefore, intraoperative hypotension can result in decreased tissue perfusion in non-critical organs such as kidneys and skeletal muscles, the latter resulting in post-anesthetic myositis; thus, maintaining adequate blood pressure during anesthesia is essential to avoid such complication.

Administration of sympathomimetic drugs is the most effective method for maintaining blood pressure and tissue perfusion during anesthesia in horses. Several drugs have been studied such as dopamine, dobutamine, phenylephrine and dopexamine (LEE et al., 1998; DUKE et al., 2006; DE VRIES et al., 2009). Among these agents, dobutamine (DBT) was the most effective in increasing intramuscular blood flow whereas dopamine, phenylephrine and dopexamine did not improve muscle perfusion (LEE et al., 1998).

Acepromazine (ACP) has been used for many years as premedication in horses. In this species, ACP decreases blood pressure, as result from peripheral alpha-adrenergic blockade resulting in vasodilation (PARRY et al., 1982; LEISE et al., 2007). Considering the effect duration, it is expected that when $\mathrm{ACP}$ is administered as premedication, its vasodilator effect might interfere with blood pressure control during the perioperative period. It has been reported that, in dogs, ACP reduces the effectiveness of sympathomimetics which act as agonists at alphaadrenergic receptors, such as dopamine and phenylephrine (LUDDERS et al., 1983; MONTEIRO et al., 2007). Dobutamine increases blood pressure as a result of its effects on myocardial beta adrenergic receptors increasing contractility and cardiac output (LEE et al., 1998). Although ACP does not possess beta adrenergic blocking properties, phenothiazineinduced decrease in systemic vascular resistance might interfere with the effectiveness of DBT in increasing blood pressure during anesthesia. This study aimed to evaluate the influence of ACP premedication on the cardiovascular effects of DBT in horses anesthetized with isoflurane (ISO).

\section{MATERIALS AND METHODS}

Six adult healthy mix-breed horses ( 5 females and 1 male) weighing $296 \pm 77 \mathrm{~kg}$ (mean \pm SD) were used. Health status was assessed by means of physical examination, a CBC and serum biochemical analyses (ALT, AST, Gamma GT, Alkaline Phosphatase, Urea and Creatinine). Horses were assigned to receive three treatments administered on different occasions, in random order, with 1-week washout intervals. In the control treatment (Control), $5 \mathrm{ml}$ of saline solution $(\mathrm{NaCl}$ $0.9 \%)$ were administered. In treatments $\mathrm{ACP}_{0.025}$ and $\mathrm{ACP}_{0.05}$, the horses received 0.025 and $0.05 \mathrm{mg} \mathrm{kg}^{-1}$ of $\mathrm{ACP}^{\mathrm{a}}$, respectively.

The horses were fasted for 12 hours prior to each experiment but had free access to water. A 14G catheter was percutaneously introduced into the right jugular vein for drug and fluid administration. Subsequently, the animals received the experimental treatment (saline or ACP). After 10 minutes, detomidine $\left(0.01 \mathrm{mg} \mathrm{kg}^{-1}\right)$ was administered IV and anesthesia was induced 10 minutes later by the IV administration of $100 \mathrm{mg} \mathrm{kg}^{-1}$ guaifenesin and $2 \mathrm{mg} \mathrm{kg}^{-1} \mathrm{ketamine}$. After endotracheal intubation, horses were positioned in left lateral recumbency on a padded surface. The endotracheal tube was connected to a circle system to allow maintenance of anesthesia with $\mathrm{ISO}^{\mathrm{b}}$, delivered via a precision vaporizer ${ }^{c}$. The vaporized concentration (ISO $\mathrm{VAP}_{\mathrm{VA}}$ ) was adjusted to maintain a moderate depth of anesthesia on the basis of clinical evaluation (absence of limb movement and nystagmus, slight palpebral reflex and strong corneal reflex). In all occasions, depth of anesthesia was evaluated by a single anesthesiologist who was unaware of which treatment was administered. The flow of oxygen was $20 \mathrm{~mL} \mathrm{~kg}^{-1}$ $\mathrm{min}^{-1}$ during the first 30 minutes, after which it was reduced to $10 \mathrm{~mL} \mathrm{~kg}^{-1} \mathrm{~min}^{-1}$. Animals had their lungs mechanically ventilated ${ }^{d}$ with the ventilator settings adjusted to maintain the end-tidal carbon dioxide concentration $\left(\mathrm{ETCO}_{2}\right)$ between 35 and $45 \mathrm{mmHg}$. The $\mathrm{ETCO}_{2}$ was measured by a capnogram ${ }^{\mathrm{e}}$ connected to the distal end of the endotracheal tube. A $20 \mathrm{G}$ catheter was introduced percutaneously into the transverse facial artery and connected to a pressure transducer filled with heparinized saline solution for displaying systolic (SAP), diastolic (DAP) and mean (MAP) blood pressures on the monitor ${ }^{\mathrm{f}}$ screen. The pressure transducer was zeroed at the level of the manubrium of the animal. Oxygen saturation $\left(\mathrm{SpO}_{2}\right)$ was measured by a pulse oximeter ${ }^{\mathrm{f}}$ whose sensor was placed at the tongue. Surface electrodes were attached to the skin according to a lead II ECG to monitor heart rate (HR) and rhythm. Lactated Ringer's solution was administered throughout the experiment.

Baseline values of the aforementioned variables were measured within 60 minutes after the onset of anesthesia at a stable concentration of ISO. After baseline measurements, administration of $\mathrm{DBT}^{\mathrm{g}}$ was initiated at the infusion rate of $0.5 \mu \mathrm{g} \mathrm{kg}^{-1} \mathrm{~min}^{-1}$ using a peristaltic infusion pump $^{\mathrm{h}}$; the DBT infusion rate was progressively increased in increments of $0.5 \mu \mathrm{g}$ 
$\mathrm{kg}^{-1} \mathrm{~min}^{-1}$ until the values of MAP reached $70 \mathrm{mmHg}$ or until a maximum dose of $5.0 \mu \mathrm{g} \mathrm{kg}^{-1} \mathrm{~min}^{-1}$. Each infusion rate was maintained for 10 minutes, after which cardiorespiratory variables and $\mathrm{ISO}_{\mathrm{VAP}}$ were recorded. The infusion rate which resulted in a 50\% increase in baseline MAP (target 1) and the infusion rate which increased MAP up to 70 $\mathrm{mmHg}$ or higher (target 2) were recorded. After target 2 or the highest rate of infusion of DBT $\left(5.0 \mu \mathrm{g} \mathrm{kg}^{-1} \mathrm{~min}^{-1)}\right.$ was reached, data was collected, ISO was discontinued and the horses were allowed to recover from anesthesia. The times elapsed between discontinuation of ISO until extubation, sternal recumbency and standing were recorded.

Normal distribution of data was checked with a Kolgomorov-Smirnov test. Comparisons among treatments in cardiorespiratory data were performed by the use of a 2-way ANOVA followed by the Bonferroni correction for multiple pairwise comparisons. The rates of infusion of DBT necessary to achieve targets 1 and 2, as well as recovery times, were compared among treatments by 1-way ANOVA followed by Tukey test. Differences over time within each treatment were compared by 1-way ANOVA followed by Dunnett test. ISO VAP concentrations obtained throughout the experimental period (from baseline to the highest infusion rate of DBT) were averaged and compared among treatments by use of Kruskal-Wallis followed by Dunn' test for multiple comparisons. Differences were considered significant at values of $P<0.05$.

\section{RESULTS}

One horse showed signs of colic few hours after standing, on the day which it underwent the control treatment. This horse was submitted to an exploratory celiotomy and was excluded from the remainder of the study. Data obtained from this horse in the control treatment and in treatment $\mathrm{ACP}_{0.05}$ (obtained a week before) were not excluded from tabulation but this horse did not undergo treatment $\mathrm{ACP}_{0.025}$.

The median (interquartile range) values of $\mathrm{ISO}_{\mathrm{VAP}}(\%)$ obtained in each treatment throughout the experimental period (from baseline to the highest infusion rate of DBT) were: 3.0 (2.0-3.0), 2.0 (1.5-2.5) and 2.5 (1.5-2.5) in the Control, $\mathrm{ACP}_{0.025}$ and $\mathrm{ACP}_{0.05}$ treatments, respectively. The median $\mathrm{ISO}_{\mathrm{VAP}}$ value in Control was significantly higher than in $\mathrm{ACP}_{0.025}$ $(P<0.001)$ and $\mathrm{ACP}_{0.05}(P<0.05)$ treatments.

There were no significant differences among treatments at baseline or during DBT infusions in mean $\mathrm{HR}, \mathrm{SAP}, \mathrm{DAP}, \mathrm{MAP}, \mathrm{ETCO}_{2}, \mathrm{SpO}_{2}$, respiratory rate and peak inspiratory pressure. The HR varied greatly among animals at DBT doses higher than $3.0 \mu \mathrm{g} \mathrm{kg}^{-1}$ $\min ^{-1}$. Heart rate increased in all treatments, but significant differences compared with baseline values were observed in the Control and $\mathrm{ACP}_{0.05}$ treatments with DBT infusions of 4.5 and $5.0 \mu \mathrm{g} \mathrm{kg}^{-1} \mathrm{~min}^{-1}$ (Figure 1). Compared with baseline, there was a significant increase in SAP, MAP and DAP in all treatments, the increase in MAP being evident with the lowest infusion rate of DBT $\left(0.5 \mu \mathrm{g} \mathrm{kg}^{-1} \mathrm{~min}^{-1}\right)$ (Figure 1). There were no differences over time in $\mathrm{ETCO}_{2}, \mathrm{SpO}_{2}$, respiratory rate and peak inspiratory pressure; $\mathrm{ETCO}_{2}$ values ranged from $36-43 \mathrm{mmHg}, \mathrm{SpO}_{2}$ was always $\geq 97 \%$, respiratory rate ranged from 8-9 breaths $\min ^{-1}$ and peak inspiratory pressures ranged from $12-17 \mathrm{~cm} \mathrm{H}_{2} \mathrm{O}$ throughout the study.

Target 2 (MAP $\geq 70 \mathrm{mmHg}$ ) was achieved in $4 / 6,3 / 5$ and $6 / 6$ animals in the Control, $\mathrm{ACP}_{0.025}$ and $\mathrm{ACP}_{0.05}$ treatments, respectively. On the four occasions that target 2 was not reached ( 2 occasions in the Control and 2 occasions in $\mathrm{ACP}_{0.025}$ ), MAP values ranged from 60 to $66 \mathrm{mmHg}$. The mean dose of DBT $( \pm \mathrm{SD})$ necessary for achieving target 1 (increase in baseline MAP by $50 \%$ ) was $1.8 \pm 1.7,2.3 \pm 1.5$ and $1.7 \pm 1.3 \mu \mathrm{g} \mathrm{kg}^{-1} \mathrm{~min}^{-1}$ and the mean dose of DBT to achieve target 2 was $3.5 \pm 1.8$, $3.7 \pm 1.6$ and $2.7 \pm 1.4 \mu \mathrm{g} \mathrm{kg}^{-1} \mathrm{~min}^{-1}$ in the Control, $\mathrm{ACP}_{0.025}$ and $\mathrm{ACP}_{0.05}$ treatments, respectively. The rate of infusion of DBT to achieve targets 1 and 2 did not differ significantly among treatments.

There was no difference among treatments in duration of anesthesia, volume of fluids administered and times to extubation, sternal recumbency and standing. The duration of anesthesia was $174 \pm 40$, $185 \pm 37$ and $156 \pm 31$ minutes (mean \pm SD) in the Control, $\mathrm{ACP}_{0.025}$ and $\mathrm{ACP}_{0.05}$ treatments, respectively. During the recovery period, the specific times observed in the Control, $\mathrm{ACP}_{0.025}$ and $\mathrm{ACP}_{0.05}$ treatments were: extubation $(23 \pm 9,21 \pm 5$ and $21 \pm 10$ minutes); sternal recumbency $(56 \pm 16,59 \pm 10$ and $64 \pm 11$ minutes); standing $(61 \pm 19,59 \pm 11$ and $68 \pm 16$ minutes), respectively. The rate of infusion of lactated Ringer's solution was $4.4 \pm 0.2$, $4.3 \pm 0.2$ and $4.0 \pm 0.3 \mathrm{~mL} \mathrm{~kg}^{-1} \mathrm{~h}^{-1}$ in the Control, $\mathrm{ACP}_{0.025}$ and $\mathrm{ACP}_{0.05}$ treatments, respectively.

\section{DISCUSSION}

In the present study, it was hypothesized that premedication with ACP would interfere with the effectiveness of DBT in increasing blood pressure in ISO-anesthetized horses and that effect was doserelated. However, no difference was observed in the cardiovascular effects of DBT among ACP treated and non-treated horses. 


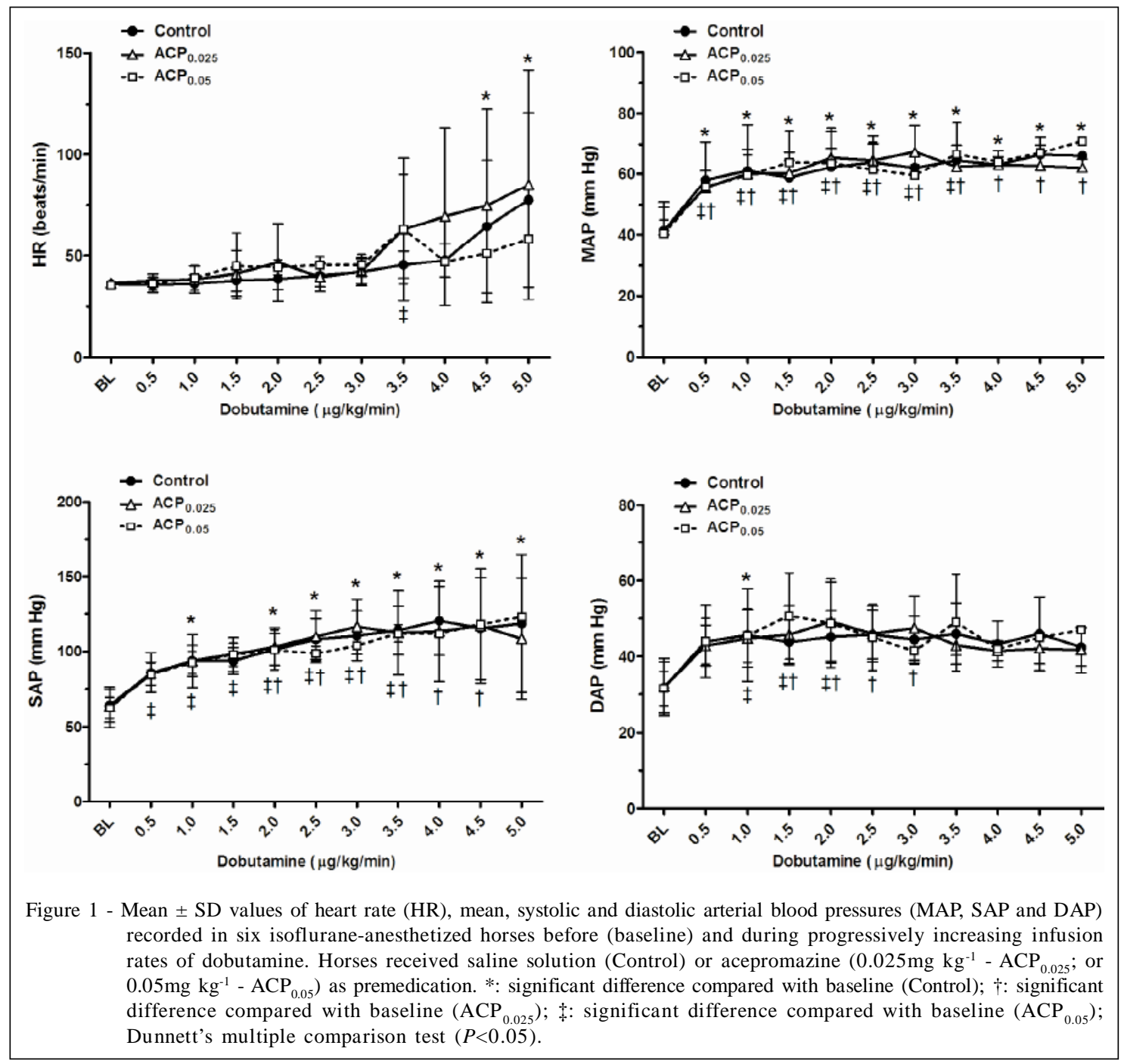

To compare the physiologic effects of anesthesia with inhalational anesthetics alone with those of inhalational anesthetics in combination with anesthetic adjuvants (eg, ACP), it is important to use doses that induce an equivalent depth of anesthesia. The minimum alveolar concentration (MAC) has been the most widely used measure to compare the physiologic effects of anesthetics, with this value determined for the inhalational anesthetic alone and with concurrent administration of the drug being evaluated (QUASHA et al., 1980). In the present study, the MAC of ISO was not determined during anesthesia with ISO alone or in combination with ACP. In this study, we recorded the $\mathrm{ISO}_{\mathrm{VAP}}$ to maintain a moderate depth of anesthesia. To reduce the subjectivity of assessing anesthetic depth, a single observer, who was unaware of the treatments administered, was responsible for evaluating the depth of anesthesia and for adjusting the vaporizer settings on all occasions. Therefore, it may be suggested that equipotent concentrations of ISO and ISO/ACP were used on the basis of clinical evaluation of anesthetic depth.

Hypotension (MAP<70 mmHg) was observed in all treatments at baseline (before administration of DBT) in the present study. Previous studies have reported that in horses anesthetized with guaifenesin, ketamine and alpha-2 agonists, in combination with halogenated anesthetics, hypotension does not occur (YAMASHITA et al., 2000; MCMURPHY et al., 2002). Therefore it is unlikely that, after a stabilization period of 60 minutes of ISO anesthesia, hypotension at baseline was caused by administration of detomidine, guaifenesin or ketamine. 
On the other hand, it has been reported that ACP and ISO reduces blood pressure mainly due to a decrease in systemic vascular resistance (STEFFEY \& HOWLAND, 1980; STEFFEY et al., 1987; LEISE et al., 2007; DE VRIES et al., 2009). In conscious horses, the effect of ACP $\left(0.05 \mathrm{mg} \mathrm{kg}^{-1}, \mathrm{IM}\right)$ on blood pressure lasts for up to 6 hours (PARRY et al., 1982) suggesting that the effect on systemic vascular resistance (SVR) is prolonged. Thus, hypotension observed at baseline in this study should be attributed to ISO alone (Control) or ISO and ACP (treatments $\mathrm{ACP}_{0.025}$ and $\mathrm{ACP}_{0.05}$ ).

During anesthesia with ISO in horses, cardiac output is preserved at superficial and moderate depth of anesthesia (STEFFEY \& HOWLAND, 1980). However, SVR is reduced even at superficial depth of anesthesia resulting in a decrease in blood pressure (STEFFEY \& HOWLAND, 1980; STEFFEY et al., 1987). Acepromazine also reduces blood pressure due to blockage of alpha- 1 adrenergic receptors resulting in decreased SVR (PARRY et al., 1982). During anesthesia with ACP and ISO, one would expect that the combined effect of drugs on the SVR would result in significant reduction in blood pressure compared with anesthesia with ISO alone. On the other hand, it was reported that in ponies, ACP $\left(0.05 \mathrm{mg} \mathrm{kg}^{-1}, \mathrm{IV}\right)$ reduces the MAC of halothane by approximately $37 \%$, allowing the use of lower anesthetic concentrations during maintenance of anesthesia (DOHERTY et al., 1997). It is possible that the reduction in $\mathrm{ISO}_{\mathrm{VAP}}$ in horses treated with $\mathrm{ACP}$, in this study, may have attenuated the effect of ISO on SVR resulting in blood pressure values not significantly different among treatments at baseline.

In the present study, the median values of ISO $_{\mathrm{VAP}}$ in each treatment, obtained throughout the experimental period (from baseline to the highest infusion rate of DBT), were approximately $33 \%$ and $17 \%$ lower in treatments $\mathrm{ACP}_{0.025}$ and $\mathrm{ACP}_{0.05}$, respectively, compared with the Control. Despite ISO $_{\mathrm{VAP}}$ did not differ significantly between treatments $\mathrm{ACP}_{0.025}$ and $\mathrm{ACP}_{0.05}$, higher concentrations of ISO were needed to maintain a moderate depth of anesthesia when the highest dose of ACP was used. These results are not unexpected since, in dogs, the decrease in the MAC of halothane was not dose-related when doses from 0.02 to $0.2 \mathrm{mg} \mathrm{kg}^{-1}$ of ACP were used (HEARD et al., 1986).

It has been reported in the literature that maintenance of MAP values of $70 \mathrm{mmHg}$ or higher reduces the likelihood of developing post-anesthetic myopathy (DUKE et al., 2006). Several sympathomimetic drugs have been studied for treatment of intraoperative hypotension in horses. However, DBT was shown to be the one that resulted in greater improvement in muscle perfusion (LEE et al., 1998). Dobutamine acts as an agonist at beta- 1 and beta- 2 receptors in the myocardium and conduction tissues, causing inotropic and chronotropic effects (LAWSON \& JOHNSON, 2001). Additionally, it acts at vascular beta- 2 receptors resulting in decreased SVR (LAWSON \& JOHNSON, 2001). Thus, the rise in blood pressure that occurs during administration of DBT results from elevation of cardiac output whereas SVR is expected to decrease. In this study, the doses of DBT required for increasing the MAP by $50 \%$ and the doses required to increase MAP to values of $70 \mathrm{mmHg}$ did not differ among the Control, $\mathrm{ACP}_{0.025}$ and $\mathrm{ACP}_{0.05}$ treatments. One possible explanation for these results is the use of lower concentrations of ISO in animals treated with ACP compared with the Control treatment, thereby attenuating the effect of ISO on SVR. Another possible explanation is that the increase in cardiac output by DBT was enough to compensate the reduction in SVR, increasing MAP as a result of increases in cardiac output.

Target 2 (MAP $\geq 70 \mathrm{mmHg}$ ) was not achieved in 2/6 horses and in 2/5 horses in the Control and $\mathrm{ACP}_{0.025}$. A few reasons might have contributed to these results: a) the horses were mechanically ventilated to maintain normocapnia; b) the horses were not subjected to noxious stimulation. In horses anesthetized under mechanical ventilation, cardiovascular depression is expected to occur unless the ventilation is adjusted to allow mild hypercapnia, considered as $\mathrm{PaCO}_{2}$ values of 50-60mmHg (KALCHOFNER et al., 2009). Also, it has been reported that in horses anesthetized for surgical procedures, DBT was effective in improving cardiovascular performance (DE VRIES et al., 2009). Although target 2 was not achieved in four occasions in this study, MAP remained between $60-66 \mathrm{mmHg}$, which is pretty close to $70 \mathrm{mmHg}$. It is possible that if ventilation was adjusted to maintain $\mathrm{ETCO}_{2}$ values above $50 \mathrm{mmHg}$ and that if these horses were submitted to noxious stimuli, target 2 would have been achieved in all horses in this study.

\section{CONCLUSION}

Under the conditions of this study, premedication with ACP at doses of 0.025 or $0.05 \mathrm{mg}$ $\mathrm{kg}^{-1}$ does not interfere with the effectiveness of DBT in increasing blood pressure in horses anesthetized with ISO. Further studies performed under clinical conditions, in the presence of noxious stimulation, are required to verify whether these results will be reproduced in such circumstances. 


\section{SOURCES AND MANUFACTURERS}

a - Acepran 1\%, Vetnil, Louveira, SP.

b - Isoforine, Cristália, Itapira, SP.

c - Vaporizador calibrado, Oxigel, São Paulo, SP.

d - Aparelho de Anestesia modelo Pegasus, Brasmed / Incotec Científica, Paulínia, SP.

e - Oxicapnógrafo modelo M2000, JG Moriya, São Paulo, SP. f - Monitor Multiparamétrico modelo Inmax Color, Instramed, Porto Alegre, RS.

g - Dobuton, Ariston, São Paulo, SP.

h - Bomba de infusão modelo Nutrimat II, B-Braun, São Gonçalo, RJ.

\section{ACKNOWLEDGEMENTS}

The authors thank Centro Universitário Vila Velha (UVV) and FUNADESP for financial support for this research.

\section{ANIMAL CARE AND ETHICS COMMITTEE}

The present study was approved by the Institutional Animal Care and Ethics Committee (protocol: 32R/2008).

\section{REFERENCES}

DE VRIES, A. et al. Effects of dobutamine on cardiac index and arterial blood pressure in isoflurane-anaesthetized horses under clinical conditions. Journal of Veterinary Pharmacology and Therapeutics, v.32, n.4, p.353-358, ago. 2009. Available from: <http://onlinelibrary.wiley.com/doi/10.1111/j.13652885.2008.01051.x/abstract> Accessed: Set. 23, 2010. doi: 10.1111/j.1365-2885.2008.01051.x.

DOHERTY, T.J. et al. Effect of acepromazine and butorphanol on halothane minimum alveolar concentration in ponies. Equine Veterinary Journal, v.29, n.5, p.374-376, set. 1997.

DUKE, T. et al. Clinical observations surrounding an increased incidence of postanesthetic myopathy in halothane-anesthetized horses. Veterinary Anaesthesia and Analgesia, v.33, n.2, p.122-127, mar. 2006. Available from: <http://onlinelibrary.wiley.com/doi/10.1111/j.14672995.2005.00189.x/abstract>. Accessed: Set. 24, 2010. doi: 10.1111/j.1467-2995.2005.00189.x.

HEARD, D.J. et al. Effect of acepromazine on the anesthetic requirement of halothane in the dog. American Journal of Veterinary Research, v.47, n.10, p.2113-2115, out. 1986.

JOHNSTON, G.M. et al. The confidential enquiry into perioperative equine fatalities (CEPEF): mortality results of Phases1and 2. Veterinary Anaesthesia and Analgesia, v.29, n.4, p.159-170, out. 2002. Available from: <http:// onlinelibrary.wiley.com/doi/ $10.1046 /$ j. 1467 2995.2002.00106.x/abstract>. Accessed: Set. 22, 2010. doi: 10.1046/j.1467-2995.2002.00106.x

KALCHOFNER, K.S. et al. A study of cardiovascular function under controlled and spontaneous ventilation in isofluranemedetomidine anaesthetized horses. Veterinary Anaesthesia and Analgesia, v.36, n.5, p.426-435, set. 2009. Available from: <http://onlinelibrary.wiley.com/ doi/10.1111/j.14672995.2009.00477.x/abstract>. Accessed: Set. 22, 2010. doi: 10.1111/j.1467-2995.2009.00477.x.

LAWSON, N.W.; JOHNSON, J.O. Autonomic nervous system: physiology and pharmacology. In: BARASH, P.G. et al. Clinical anesthesia. Philadelphia: Lippincott Williams \& Wilkins, 2001. Cap.12, p.261-325.

LEE, Y.K. et al. Effects of dopamine, dobutamine, dopexamine, phenylephrine, and saline solution on intramuscular blood flow and other cardiopulmonary variables in halothane-anesthetized ponies. American Journal of Veterinary Research, v.59, n.11, p.1463-1472, nov. 1998.

LEISE, B.S. et al. Effects of intramuscular administration of acepromazine on palmar digital blood flow, palmar digital arterial pressure, transverse facial arterial pressure, and packed cell volume in clinically healthy, conscious horses. Veterinary Surgery, v.36, n.8, p.717-723, dec. 2007. Available from: <http://onlinelibrary.wiley.com/doi/10.1111/j.1532950X.2007. 00325.x/abstract>. Accessed: Set. 22, 2010. doi: 10.1111/j.1532-950X.2007.00325.x.

LUDDERS, J.W. et al. Blood pressure response to phenylephrine infusion in halothane-anesthetized dogs given acetylpromazine maleate. American Journal of Veterinary Research, v.44, n.6, p.996-999, jun. 1983.

MONTEIRO, E.R. et al. Effects of acepromazine on the cardiovascular actions of dopamine in anesthetized dogs. Veterinary Anaesthesia and Analgesia, v.34, n.5, p.312321, set. 2007. Available from: <http://onlinelibrary.wiley.com/ doi/10.1111/j.1467-2995.2006.00328.x/abstract>. Accessed: Set. 22, 2010. doi: 10.1111/j.1467-2995.2006.00328.x.

PARRY, B.W. et al. Hypotension in the horse induced by acepromazine maleate. Australian Veterinary Journal, v.59, n.5, p.148-152, nov. 1982. Available from: <http:// onlinelibrary.wiley.com/doi/ $10.1111 /$ j. 1751 0813.1982.tb02761.x/abstract>. Accessed: Set. 22, 2010. doi: 10.1111/j.1751-0813.1982.tb02761.x.

QUASHA, A.L. et al. Determination and applications of MAC. Anesthesiology, v.53, n.4, p.315-334, out. 1980.

STEFFEY, E.P.; HOWLAND, D.JR. Comparison of circulatory and respiratory effects of isoflurane and halothane anesthesia in horses. American Journal of Veterinary Research, v.41, n.5, p.821-825, maio, 1980.

STEFFEY, E.P. et al. Cardiovascular and respiratory measurements in awake and isoflurane-anesthetized horses. American Journal of Veterinary Research, v.48, n.1, p.712, jan. 1987.

YAMASHITA, K. et al. Combination of continuous intravenous infusion using a mixture of guaifenesin-ketamine-medetomidine and sevoflurane anesthesia in horses. Journal of Veterinary Medical Science, v.62, n.3, p.229-235, mar. 2000. Available from: 〈http://www.jstage.jst.go.jp/article/jvms/62/3/229/_pdf〉. Accessed: Set. 22, 2010. doi: 10.1292/jvms.62.229. 